\title{
Influence of Different Apical Preparations on Root Canal Cleanliness in Human Molars: a SEM Study
}

\author{
Gianluca Plotino ${ }^{1}$, Nicola M. Grande ${ }^{1}$, Luigi Tocci ${ }^{1}$, Luca Testarelli ${ }^{1}$, Gianluca Gambarini ${ }^{1}$ \\ ${ }^{1}$ Department of Endodontics, "Sapienza” University of Rome, Italy.
}

\author{
Corresponding Author: \\ Gianluca Plotino \\ Via Calabria 25 - 00187 Rome \\ Italy \\ E-mail: endo@gianlucaplotino.com
}

\section{ABSTRACT}

Objectives: To compare the influence of type and dimensions of the apical preparation on the cleanliness of the apical area in molars.

Material and Methods: A total of 120 root canals (MB and DB root canals from 30 maxillary molars and mesial root canals from 30 mandibular molars) were instrumented with Mtwo NiTi rotary instruments to a size 25/0.06 taper and were equally divided into three different experimental groups depending on the subsequently apical root canal preparation: Group 1: no further apical preparation, Group 2: apical preparation with Mtwo files to a size 40/0.04 taper, Group 3: apical preparation with Mtwo Apical Files. All root canals were observed through scanning electron microscopy (SEM). Presence of superficial debris and smear layer was evaluated using a score system. Data were statistically analysed using the Kruskal-Wallis and Bonferroni tests with a level of significance set at $\mathrm{P}<0.05$.

Results: Kruskal-Wallis test revealed no differences among groups in the middle and coronal third $(\mathrm{P}>0.05)$, while at the apical level, there was a significant difference for both residual debris and presence of smear layer between Group 1 and both Group $2(\mathrm{P}=0.003$ and $\mathrm{P}=0.014)$ and $3(\mathrm{P}=0.012$ and $\mathrm{P}=0.021)$, while no difference was present between Group 2 and Group $3(\mathrm{P}=0.871$ and $\mathrm{P}=0.923)$.

Conclusions: Cleanliness of the apical third in terms of debris and smear layer was statistically better when an apical preparation was performed to a size 40/0.04 taper or with the use of the Mtwo Apical Files.

Keywords: nickel-titanium alloy; root canal preparation; scanning electron microscopy.

\section{Accepted for publication: 13 April 2014}

To cite this article:

Plotino G, Grande NM, Tocci L, Testarelli L, Gambarini G. Influence of Different Apical Preparations on Root Canal Cleanliness in Human Molars: a SEM Study.

J Oral Maxillofac Res 2014;5(2):e4

URL: http://www.ejomr.org/JOMR/archives/2014/2/e4/v5n2e4ht.pdf

doi: $10.5037 /$ jomr.2014.5204 


\section{INTRODUCTION}

Primary objective of root canal therapy is to thoroughly cleanse the root canal system, removing microorganisms and their substrates and organic and inorganic contents from the canal space [1]. Without proper chemomechanical instrumentation, the remaining irritants may reduce the success rate and cause failure of the treatment [2]. However, it remains one of the most difficult challenges in endodontic therapy [3]. Many studies have demonstrated that chemomechanical preparation of the root canal may result in a significant reduction of bacteria, but will not reproducibly leave bacteria-free root canals [4-6]. These objectives are more difficult to achieve in complex anatomical spaces, such as oval canals, in which it may be difficult to instrument the entire walls and not well cleaned recesses and infected dentine may remain after chemical and mechanical preparation []].

The final apical preparation size further remains matter of debate []. To overcome the potential limits of instrumentation and irrigation in the apical area, enlargement of this area has been advocated for better cleansing [ $[5,6,9-11]$. In this regard, apical root-canal preparation by mechanical canal shaping has an antimicrobial effect via canal debridement $[\underline{4}, \underline{5}, \underline{11-13}]$. Many studies have demonstrated that debris are more effectively removed when the apical preparation size is large $[5, \underline{6}, \underline{9}, \underline{10}, \underline{14}]$. Other studies have demonstrated that widely accepted endodontic cleaning and shaping techniques are inadequate $[\underline{9}, \underline{15}, \underline{16}]$. This inadequate instrumentation could be attributed to the fact that root canal diameter is larger than the instrument caliber often used [17].

Recently, rotary files specifically designed for the apical preparation have been introduced on the market (Mtwo Apical Files, Sweden \& Martina, Padova, Italy; Hero Apical, Micro-Mega, Besancon, France). The Mtwo endodontic instruments are a new type of NiTi rotary instruments for root canal preparation. The Mtwo system has been completed with 3 rotary files specifically designed for the apical preparation, the Mtwo Apical Files (A). The 3 apical files vary in tip size and taper. The innovative feature of these instruments is the high taper of the last apical millimeter. The A1 instrument presents a tip size (D0) of $0.2 \mathrm{~mm}$ and $15 \%$ taper in the first millimeter, thus measuring $0.35 \mathrm{~mm}$ in D1. A2 instrument presents a tip size (D0) of $0.25 \mathrm{~mm}$ and $15 \%$ taper in the first millimeter, thus measuring 0.4 $\mathrm{mm}$ in D1. A3 instrument presents a tip size (D0) of $0.25 \mathrm{~mm}$ and $20 \%$ taper in the first millimeter, thus measuring $0.45 \mathrm{~mm}$ in $\mathrm{D} 1$. The remaining portion of these instruments, from D1 to D16, present a $2 \%$ taper. To obtain this design, the apical millimeter of the instrument is not spiralized but it has two straight blades while maintaining a rounded non-cutting end. This design has been developed to obtain bigger preparation diameters in the apical portion of the root canals maintaining the anatomy of the apical foramen. The enhanced taper in the apical zone also provides resistance form against the condensation pressures of obturation and acts to prevent the extrusion of the filling material.

The aim of the present study was to compare the influence of type and dimensions of the apical preparation on the cleanliness of the apical area in molars by means of a scanning electron microscope analysis. The null hypothesis tested in the present study was that no difference in canal wall cleanliness exists between the different apical preparations used.

\section{MATERIAL AND METHODS Selection of samples}

30 maxillary and 30 mandibular sound freshly extracted molars of similar length were selected for this study from a pool of extracted teeth. Mesiobuccal (MB) and disto-buccal (DB) root canals of the maxillary molars and the mesial root canals from the mandibular molars have been used. The teeth were stored in 0.1 thymol solution at room temperature and placed into $5.25 \%$ sodium hypochlorite solution for 20 minutes to remove the periodontal ligament. All remaining organic residues were removed from external root surfaces with a scaler, with careful examination under stereomicroscope at magnification x30 (Stemi SV6, Carl Zeiss S.p.A., Arese, Italy) to check for root fractures and to confirm that apex formation was complete. Roots with open apices, signs of apical root resorption and fracture lines were discarded.

The cusps were flattened and access to the pulp chamber was established with a cylindrical diamond bur (Komet \# 6881, Komet-Brasseler, Lemgo, Germany) using a high-speed handpiece under copious water-cooling. The crowns were not removed at the level of the cementoenamel junction in order to preserve the normal trajectory of NiTi rotary instruments. After the root canal orifices were identified, patency of the MB and DB canals of the maxillary molars and $\mathrm{MB}$ and mesio-lingual (ML) canals of the mandibular molars was determined by using a size $10 \mathrm{~K}$-Flexofile (Dentsply-Maillefer, Baillagues, Switzerland) to discard teeth with canal 
obstructions. Two traditional analogic radiographs were taken in a bucco-lingual and mesio-distal direction for studying root canal anatomy and identify the radiographic apex. Teeth were fixed with wax on the X-ray film to maintain them perpendicular to the X-ray source and avoid movement during $\mathrm{X}$-ray exposure. The radiographs were used to detect canals that joined each other. Only mesial roots of mandibular molars with two separate canals were included in the study. MB2 canals of maxillary molars were not used in the present study. If mesial root canals of mandibular molars were confluent they were discarded and replaced with specimens with separate root canals as confirmed radiographically. Only roots that demonstrated moderate curvatures $\left(<10^{\circ}\right)[\underline{18}]$ were selected for this study and roots with abrupt apical curvatures (with a radius of curvature $\leq 2 \mathrm{~mm}$ in the last $3 \mathrm{~mm}$ ) were also excluded.

\section{Root canal preparation}

A single experienced operator (GP) prepared all root canals. Root canal working length was visually determined for each canal by inserting the size 10 K-Flexofile into each canal until the tip of the file became visible at the major foramen under $20 \mathrm{X}$ stereomicroscope and subtracting $0.5 \mathrm{~mm}$ from this measurement.

A total of 120 root canals were instrumented with Mtwo NiTi rotary instruments in a simultaneous technique to a size 25/0.06 taper (instrumentation sequence tip size/taper: 10/0.04, 15/0.05, 20/0.06, $25 / 0.06)$ and were equally divided (10 MB and 10 $\mathrm{DB}$ root canals of maxillary molars and $10 \mathrm{MB}$ and $10 \mathrm{ML}$ root canals of mandibular molars) into three different experimental groups depending on the subsequently apical root canal preparation: Group 1: no further apical preparation was performed; Group 2: apical preparation with Mtwo files using the instruments tip size 30/0.05 taper, size 35/.04 taper to a size 40/0.04 taper; Group 3: apical preparation with Mtwo Apical Files using the instruments A1 and A2.

NiTi rotary instruments were powered at $280 \mathrm{rpm}$ using a torque control motor with torque values already established for each Mtwo instrument (Silver Motor, VDW, Munich, Germany). NiTi Mtwo instruments tip size/taper 10/0.04, 15/0.05, 20/0.06, 25/0.06 were used in a simultaneous technique [19]. Instruments were each taken to working length with light apical pressure. As soon as the clinician felt a binding sensation, the instrument was withdrawn $1-2 \mathrm{~mm}$ so that it could be worked in a brushing action to selectively remove the interferences and to advance towards the apex. The instruments were used with lateral pressure in order to obtain a circumferential cut and allowed to rotate for few seconds after reaching the full length, before proceeding to the next size. Mtwo instruments tip size 30/0.05 taper, size 35/0.04 taper to a size 40/0.04 taper and Apical Files A1 and A2 were only used in an up and down motion till the working length has been reached. The patency of the apical foramen was checked by passing the tip of a size 08 file through the foramen after each instrument of the Mtwo sequence until completion of the root canal shaping. Each instrument was used to prepare maximum 5 root canals. Instruments with any sign of fracture or deformation have been discarded and replaced. Roots were embedded in polivinilsyloxane in order to not visualize the foramen during root canal instrumentation and to simulate presence of the surrounding tissues.

The same irrigation protocol was used for the different groups. All root canals were irrigated with $2.5 \mathrm{ml}$ of $5.25 \%$ sodium hypochlorite (Niclor 5, Ogna, Muggiò, Italy) after each instrument and with $5 \mathrm{ml}$ of $17 \%$ EDTA for 2 minutes after the last flush with sodium hypochlorite subsequently to the last instrument used at the end of the preparation. A final flush with 2.5 $\mathrm{ml}$ of sterile saline solution has been used to wash out all irrigant remnants. All irrigation procedures were performed by syringe and a 30-gauge needle (Navy Tip, Ultradent Products, South Jordan, USA). The needle was inserted $1 \mathrm{~mm}$ short of the binding point during instrumentation, and $1 \mathrm{~mm}$ short of the working length for the final irrigations after the preparation.

\section{Scanning electron microscopy (SEM) preparation and analysis}

All root canals were observed through scanning electron microscopy (SEM) to evaluate canal wall cleanliness in the coronal, middle and apical third, by measuring them after splitting before SEM analysis. The roots were split longitudinally as reported by $\mathrm{Wu}$ and Wesselink [9]. Two shallow longitudinal grooves were cut on each root in a bucco-lingual direction; care was taken that the grooves followed the curvature and did not penetrate into the canal. The roots were then split with a mallet and chisel made up of an adapted cementum spatula, resulting in a mesial and distal half of the root canal. Both halves were prepared for SEM investigation (Philips SEM 515, Eindhoven, the Netherlands). Representative photomicrographs were taken at different magnifications (x200, x1000).

A grading system was used to score the amount of 
superficial debris and presence of smear layer according to the classification of Gutmann et al. [20], establishing a different score for the coronal, middle, and apical portions of the root canal of each section. The following criteria were used for debris evaluation (6- 8 microscopic fields at magnification $\mathrm{x} 200$ ): 1 none to slight presence of superficial debris covering up to the $25 \%$ of the dentinal surface, 2 little to moderate presence of debris covering between $25 \%$ and $50 \%$ of the surface, 3 moderate to heavy presence of residual debris covering between 50\% and $75 \%$ of the surface, 4 heavy amount of aggregated or scattered debris covering over $75 \%$ of the surface. The following criteria were used for smear layer evaluation (12 fields at magnification x1000): 1 little or no smear layer, covering less than $25 \%$ of the specimen; tubules visible and patent, 2 little to moderate or patchy amounts of smear layer, covering between $25 \%$ and $50 \%$ of the specimen; many tubules visible and patent, 3 moderate amounts of scattered or aggregated smear layer, covering between 50\% and $75 \%$ of the specimen; minimal to no tubules visible or patent, 4 heavy smear layer covering over $75 \%$ of the specimen; no tubule orifices visible or patent.

The evaluations were carried out blindly by three operators who were unaware of the treatments that were rendered. Prior to scoring the test specimens, the examiners reviewed samples to ensure calibration and to reach a mutual understanding as to what amounts of superficial debris, smear layer, and patent or blocked dentinal tubules constituted each ranking from 1 to 4. Four photomicrographs of the superficial debris (x200) and four of the smeared layer (x1000) were taken to represent the four gradations of the scoring system. These photomicrographs served as visual reference standards for the examiners during the scoring of the test specimens. When different scores were attributed a discussion has been made between the evaluators to find an agreement.

\section{Statistical analysis}

Data were analysed using the Kruskal-Wallis test and Bonferroni multiple range test for multiple group comparisons. Statistical significance was considered at $\mathrm{P}<0.05$.

\section{RESULTS}

9 specimens (3 from Group 1, 2 from Group 2 and 4 from Group 3) were excluded from the study because they could not be evaluated due to damage occurring during sample preparation for SEM analysis.

The results of SEM analysis of the root canal walls concerning residual debris and smear layer are summarized in Table 1 and 2.

Kruskall-Wallis test revealed a statistical difference among groups in both residual debris and smear layer evaluation for what concern the apical third $(\mathrm{P}=0.0001)$, while no differences among groups have been reported in the middle and coronal third $(\mathrm{P}>0.05)$.

In terms of residual debris in the apical third, there was a significant difference between Group 1 and both Group $2(\mathrm{P}=0.003$, Bonferroni test $)$ and $3(\mathrm{P}=0.012$, Bonferroni test), while no difference was present between Group 2 and Group $3(\mathrm{P}=0.871$, Bonferroni test).

Table 1. Number of specimens registered for each score in the different root canal thirds in the evaluation of residual superficial debris

\begin{tabular}{|c|c|c|c|c|}
\hline & Score & Group $1(n=74)$ & Group $2(n=76)$ & Group $3(n=72)$ \\
\hline \multirow{4}{*}{ Coronal third } & 1 & $64^{\mathrm{a}}$ & $68^{\mathrm{a}}$ & $64^{\mathrm{a}}$ \\
\hline & 2 & $8^{\mathrm{a}}$ & $6^{\mathrm{a}}$ & $6^{\mathrm{a}}$ \\
\hline & 3 & $4^{\mathrm{a}}$ & $2^{\mathrm{a}}$ & $1^{\mathrm{a}}$ \\
\hline & 4 & $0^{\mathrm{a}}$ & $0^{\mathrm{a}}$ & $0^{\mathrm{a}}$ \\
\hline \multirow{4}{*}{ Middle third } & 1 & $50^{\mathrm{a}}$ & $48^{\mathrm{a}}$ & $44^{\mathrm{a}}$ \\
\hline & 2 & $12^{\mathrm{a}}$ & $18^{\mathrm{a}}$ & $14^{\mathrm{a}}$ \\
\hline & 3 & $10^{\mathrm{a}}$ & $8^{\mathrm{a}}$ & $10^{\mathrm{a}}$ \\
\hline & 4 & $2^{a}$ & $2^{a}$ & $4^{\mathrm{a}}$ \\
\hline \multirow{4}{*}{ Apical third } & 1 & $4^{\mathrm{a}}$ & $20^{\mathrm{b}}$ & $16^{\mathrm{b}}$ \\
\hline & 2 & $24^{\mathrm{a}}$ & $38^{\mathrm{b}}$ & $36^{\mathrm{b}}$ \\
\hline & 3 & $36^{\mathrm{a}}$ & $14^{\mathrm{b}}$ & $16^{\mathrm{b}}$ \\
\hline & 4 & $10^{\mathrm{a}}$ & $4^{a}$ & $4^{\mathrm{a}}$ \\
\hline
\end{tabular}

Note: Different superscript letters indicate statistical significant differences $(\mathrm{P}<0.05)$ among groups using the Kruskal-Wallis test and Bonferroni multiple range test for multiple group comparisons. 
Table 2. Number of specimens registered for each score in the different root canal thirds in the evaluation of residual smear layer

\begin{tabular}{ccccc}
\hline & Score & Group 1 (n=74) & Group 2 (n=76) & Group 3 (n=72) \\
\hline \multirow{4}{*}{ Coronal third } & $\mathbf{1}$ & $60^{\mathrm{a}}$ & $58^{\mathrm{a}}$ & $58^{\mathrm{a}}$ \\
\cline { 2 - 5 } & $\mathbf{2}$ & $6^{\mathrm{a}}$ & $6^{\mathrm{a}}$ & $8^{\mathrm{a}}$ \\
\cline { 2 - 5 } & $\mathbf{3}$ & $4^{\mathrm{a}}$ & $10^{\mathrm{a}}$ & $2^{\mathrm{a}}$ \\
\cline { 2 - 5 } & $\mathbf{4}$ & $4^{\mathrm{a}}$ & $2^{\mathrm{a}}$ & $4^{\mathrm{a}}$ \\
\hline \multirow{3}{*}{ Middle third } & $\mathbf{1}$ & $52^{\mathrm{a}}$ & $48^{\mathrm{a}}$ & $48^{\mathrm{a}}$ \\
\cline { 2 - 5 } & 2 & $8^{\mathrm{a}}$ & $14^{\mathrm{a}}$ & $8^{\mathrm{a}}$ \\
\cline { 2 - 5 } & $\mathbf{3}$ & $6^{\mathrm{a}}$ & $8^{\mathrm{a}}$ & $12^{\mathrm{a}}$ \\
\cline { 2 - 5 } & $\mathbf{4}$ & $8^{\mathrm{a}}$ & $6^{\mathrm{a}}$ & $4^{\mathrm{a}}$ \\
\hline \multirow{3}{*}{ Apical third } & $8^{\mathrm{a}}$ & $30^{\mathrm{b}}$ & $30^{\mathrm{b}}$ \\
\cline { 2 - 5 } & $\mathbf{2}$ & $4^{\mathrm{a}}$ & $40^{\mathrm{a}}$ & $36^{\mathrm{a}}$ \\
\cline { 2 - 5 } & $\mathbf{3}$ & $2^{\mathrm{a}}$ & $4^{\mathrm{b}}$ & $4^{\mathrm{b}}$ \\
\cline { 2 - 5 } & 4 & $4^{\mathrm{a}}$ & $2^{\mathrm{a}}$ & $2^{\mathrm{a}}$ \\
\hline
\end{tabular}

Note: Different superscript letters indicate statistical significant differences $(\mathrm{P}<0.05)$ among groups using the Kruskal-Wallis test and Bonferroni multiple range test for multiple group comparisons.

In terms of presence of smear layer, there was a significant difference between Group 1 and Group 2 $(\mathrm{P}=0.014$, Bonferroni test) and Group 1 and Group 3 $(\mathrm{P}=0.021$, Bonferroni test $)$. Differences between Group 2 and 3 were not significant $(\mathrm{P}=0.923$, Bonferroni test).

\section{DISCUSSION}

Thorough instrumentation of the apical region has long been considered to be an essential component in the cleaning and shaping process [8]. The last few millimeters that approach the apical foramen are critical in the instrumentation process $[\underline{8}, \underline{21}]$, as it is the region that most likely harbours intraradicular bacteria associated with root canal treatment failure [22].

Mechanical instrumentation and irrigation are sound endodontic principles and essential components of successful endodontics. Research has shown that mechanical instrumentation greatly reduces the number of microorganisms remaining in the root canal system [4]. Mechanical instrumentation has been shown to reduce bacterial count even without irrigants or dressings [23]. However, irrigation with antimicrobial solutions is required to further reduce the number of microorganisms to clinically acceptable levels $[\underline{4}, \underline{10}, \underline{24}]$. Furthermore, mechanical instrumentation with irrigation does not reliably disinfect an infected root canal system $[\underline{5}, \underline{6}, \underline{25}]$. In this regard, apical root-canal preparation by mechanical canal shaping has been advocated to obtain an antimicrobial effect via canal debridement $[\underline{5}, \underline{6}, \underline{9-11}]$. The results of the present study showed that a root canal preparation to a size 40/0.04 taper resulted in less residual debris and presence of smear layer in the apical third compared with the size 25/0.06 taper preparation, in agreement with other studies that have found better canal apical cleanliness with apical preparation $[\underline{6}, \underline{10}, 26]$. When the apical preparation was performed with the Mtwo Apical Files, no significant difference was found with the preparation to a size 40/0.04 taper. In the present study, no differences have been reported between the three groups in the middle and coronal thirds of the root canals. These results were expected because the preparation used in all the groups differed only in the apical third. In fact, after a common basic preparation to size 25/0.06 taper, the apical preparation to size 40/0.04 taper in Group 2 determined that the three instruments used (30/0.05, 35/0.04 and 40/0.04) touched only $8 \mathrm{~mm}$ of the root canal, reaching at this point a diameter of $0.72 \mathrm{~mm}$ versus $0.73 \mathrm{~mm}$ obtained initially by size $25 / 0.06$ taper. The same concept is for group 3 in which the preparation with A1 and A2 Apical File touched only $4 \mathrm{~mm}$ of the root canal, reaching at this point a diameter of $0.46 \mathrm{~mm}$ versus $0.49 \mathrm{~mm}$ obtained initially by size $25 / 0.06$ taper.

Furthermore, the results of the present study reported that a basic preparation to an instrument 25/0.06 taper is able to obtain a good cleanliness of the middle and apical third of root canals. This is probably due to the fact that, despite a complete contact between instruments and root canal walls is not possible, the dimensions of this basic preparation enlarge sufficiently the middle and coronal thirds to permit the irrigants to act well in these areas. Differently, in the apical third the differences between groups were statistically significant. In fact, the apical preparation 
performed by two different approaches, revealed statistically cleaner root canal walls. It should be explained by the fact that debris created by root canal preparation may be more easily removed both mechanically and chemically when dimensions of the apical third have been enhanced, and that chelating agents may reach more efficiently the apex and may remove better the smear layer.

Explanation for these results may be also related to the benefits of using greater volume of irrigant, thus increasing the time of action during the preparation [27]. In fact, for Group 2 and 3, three and two instruments more than group 1 have been used respectively, so that three and two cycles of irrigation more have been performed respectively for Group 2 and 3. Furthermore, despite a flexible 30 -gauge needle has been used in the present study as previously advocated to optimise the effectiveness of the irrigation [28,29], the diameter of the 30 gauge needles used in this study was $0.31 \mathrm{~mm}$, exactly as the diameter obtained $1 \mathrm{~mm}$ short of the apex with the instrument $25 / 0.06$. This correspondence in dimensions may have created more difficulties to the needle to reach the distance of $1 \mathrm{~mm}$ from the working length and irrigation may have been performed less efficiently than Group 2 and 3 in which at the end of the preparation a diameter of 0.44 $\mathrm{mm}$ and $0.4 \mathrm{~mm}$ have been reached in that point.

The observation that an enlarged apical preparation permits a better debridement of the apical third obtained in the present study corroborates results obtained by several studies $[\underline{5}, \underline{6}, \underline{9}, \underline{10}]$. Albrecht et al. [14] suggested that debris were more effectively removed using 0.04, 0.06, and 0.08 ProFile GT instruments when the apical preparation size was larger (size \#40) compared with size \#20 apical preparations. When a taper of 0.10 could be produced at the apical extent of the canal, there was no difference in debris removal between the two preparations sizes. All these articles report on the significance of apical third preparation for better cleaning and irrigation process, as underlined by van der Sluis et al. [30].

Clearly, a continuous taper 0.10 root canal preparation is often impossible to obtain, especially in small roots as used in the present study or in particularly curved root canals. In these situation, it seem useful the use of instruments like the Mtwo apical files which maintain the apical foramen small (size \#25) while enhancing dimensions of the apical millimetres through an exaggerate taper in the last millimetre of the instrument or to use for the apical preparation a sequence of instruments with progressively less taper (i.e. Mtwo instruments tip size 30/0.05 taper, 35/0.04 and 40/0.04).

Despite apical preparation seems to be necessary as the most predictable way to clean and disinfect root canals to prevent apical periodontitis [31], especially in the most difficult anatomies [32], no study to date has shown a definitive relationship between apical preparation and clinical success or failure. Clinical seriously conducted prospective studies are mandatory to corroborate in vitro or ex vivo studies.

\section{CONCLUSIONS}

The null hypothesis has been rejected. In fact, the results of the present study showed that apical canal wall cleanliness was better when an apical preparation has been performed after a basic preparation of size 25/0.06 taper, irrespective of the technique used to perform the apical preparation.

No differences in terms of residual debris and smear layer evaluation have been reported among groups in the middle and coronal third of root canals.

\section{ACKNOWLEDGMENTS AND DISCLOSURE STATEMENTS}

The authors deny any conflicts of interest.

The authors affirm that we have no financial affiliation (e.g., employment, direct payment, stock holdings, retainers, consultantships, patent licensing arrangements or honoraria), or involvement with any commercial organization with direct financial interest in the subject or materials discussed in this manuscript, nor have any such arrangements existed in the past three years. Any other potential conflict of interest is disclosed. 


\section{REFERENCES}

1. Wu MK, Dummer PM, Wesselink PR. Consequences of and strategies to deal with residual posttreatment root canal infection. Int Endod J. 2006 May;39(5):343-56. Review. [Medline: 16640632] [doi: $10.1111 / \mathrm{j} .1365-2591.2006 .01092 . x$ ]

2. Friedman S. Prognosis of initial endodontic therapy. Endodontic Topics 2002 Jul;2(1):59-88. [doi: 10.1034/j.1601-1546.2002.20105.x]

3. Hülsmann M, Peters OA, Dummer PMH. Mechanical preparation of root canals: shaping goals, techniques and means. Endodontic Topics 2005 Aug;10(1):30-76. [doi: 10.1111/j.1601-1546.2005.00152.x]

4. Byström A, Sundqvist G. Bacteriologic evaluation of the efficacy of mechanical root canal instrumentation in endodontic therapy. Scand J Dent Res. 1981 Aug;89(4):321-8. [Medline: 6947391]

5. Orstavik D, Kerekes K, Molven O. Effects of extensive apical reaming and calcium hydroxide dressing on bacterial infection during treatment of apical periodontitis: a pilot study. Int Endod J. 1991 Jan;24(1):1-7. [Medline: 1917083] [doi: 10.1111/j.1365-2591.1991.tb00863.x]

6. Siqueira JF Jr, Lima KC, Magalhães FA, Lopes HP, de Uzeda M. Mechanical reduction of the bacterial population in the root canal by three instrumentation techniques. J Endod. 1999 May;25(5):332-5. [Medline: 10530256] [doi: 10.1016/S0099-2399(06)81166-0]

7. Wu MK, Wesselink PR. A primary observation on the preparation and obturation of oval canals. Int Endod J. 2001 Mar;34(2):137-41. [Medline: 11307262] [doi: 10.1046/j.1365-2591.2001.00361.x]

8. Baugh D, Wallace J. The role of apical instrumentation in root canal treatment: a review of the literature. J Endod. 2005 May;31(5):333-40. Review. [Medline: 15851925] [doi: 10.1097/01.don.0000145422.94578.e6]

9. Wu MK, Wesselink PR. Efficacy of three techniques in cleaning the apical portion of curved root canals. Oral Surg Oral Med Oral Pathol Oral Radiol Endod. 1995 Apr;79(4):492-6. [Medline: 7614212] [doi: 10.1016/S1079-2104(05)80134-9]

10. Shuping GB, Orstavik D, Sigurdsson A, Trope M. Reduction of intracanal bacteria using nickel-titanium rotary instrumentation and various medications. J Endod. 2000 Dec;26(12):751-5. [Medline: 11471648] [doi: 10.1097/00004770-200012000-00022]

11. Mickel AK, Chogle S, Liddle J, Huffaker K, Jones JJ. The role of apical size determination and enlargement in the reduction of intracanal bacteria. J Endod. 2007 Jan;33(1):21-3. Epub 2006 Oct 19. [Medline: 17185122] [doi: 10.1016/j.joen.2006.08.004]

12. Card SJ, Sigurdsson A, Orstavik D, Trope M. The effectiveness of increased apical enlargement in reducing intracanal bacteria. J Endod. 2002 Nov;28(11):779-83. [Medline: 12470024] [doi: 10.1097/00004770-200211000-00008]

13. Rollison S, Barnett F, Stevens RH. Efficacy of bacterial removal from instrumented root canals in vitro related to instrumentation technique and size. Oral Surg Oral Med Oral Pathol Oral Radiol Endod. 2002 Sep;94(3):366-71. [Medline: 12324795] [doi: 10.1067/moe.2002.126164]

14. Albrecht LJ, Baumgartner JC, Marshall JG. Evaluation of apical debris removal using various sizes and tapers of ProFile GT files. J Endod. 2004 Jun;30(6):425-8. [Medline: 15167472] [doi: 10.1097/00004770-200406000-00012]

15. Gutiérrez JH, Jofré A, Villena F. Scanning electron microscope study on the action of endodontic irrigants on bacteria invading the dentinal tubules. Oral Surg Oral Med Oral Pathol. 1990 Apr;69(4):491-501. [Medline: 2326039] [doi: 10.1016/0030-4220(90)90385-6]

16. Tan BT, Messer HH. The quality of apical canal preparation using hand and rotary instruments with specific criteria for enlargement based on initial apical file size. J Endod. 2002 Sep;28(9):658-64. [Medline: 12236311] [doi: 10.1097/00004770-200209000-00008]

17. Wu MK, R'oris A, Barkis D, Wesselink PR. Prevalence and extent of long oval canals in the apical third. Oral Surg Oral Med Oral Pathol Oral Radiol Endod. 2000 Jun;89(6):739-43. [Medline: 10846130] [doi: $10.1067 /$ moe.2000.106344]

18. Schneider SW. A comparison of canal preparations in straight and curved root canals. Oral Surg Oral Med Oral Pathol. 1971 Aug;32(2):271-5. [Medline: 5284110] [doi: 10.1016/0030-4220(71)90230-1]

19. Plotino G, Grande NM, Sorci E, Malagnino VA, Somma F. A comparison of cyclic fatigue between used and new Mtwo Ni-Ti rotary instruments. Int Endod J. 2006 Sep;39(9):716-23. [Medline: 16916361] [doi: 10.1111/j.1365-2591.2006.01142.x]

20. Gutmann JL, Saunders WP, Nguyen L, Guo IY, Saunders EM. Ultrasonic root-end preparation. Part 1. SEM analysis. Int Endod J. 1994 Nov;27(6):318-24. [Medline: 7751066] [doi: 10.1111/j.1365-2591.1994.tb00276.x]

21. Spångberg L. The wonderful world of rotary root canal preparation. Oral Surg Oral Med Oral Pathol Oral Radiol Endod. 2001 Nov;92(5):479. [Medline: 11709677] [doi: 10.1067/moe.2001.120438]

22. Nair PN, Sjögren U, Krey G, Kahnberg KE, Sundqvist G. Intraradicular bacteria and fungi in root-filled, asymptomatic human teeth with therapy-resistant periapical lesions: a long-term light and electron microscopic follow-up study. J Endod. 1990 Dec;16(12):580-8. [Medline: 2094761] [doi: 10.1016/S0099-2399(07)80201-9] 
23. Byström A, Sundqvist G. Bacteriologic evaluation of the effect of 0.5 percent sodium hypochlorite in endodontic therapy. Oral Surg Oral Med Oral Pathol. 1983 Mar;55(3):307-12. [Medline: 6572884] [doi: $10.1016 / 0030-4220(83) 90333-\mathrm{X}$ ]

24. Ingle JI, Zeldow BJ. An evaluation of mechanical instrumentation and the negative culture in endodontic therapy. J Am Dent Assoc. 1958 Oct;57(4):471-6. [Medline: 13575076]

25. Pataky L, Iványi I, Grigár A, Fazekas A. Antimicrobial efficacy of various root canal preparation techniques: an in vitro comparative study. J Endod. 2002 Aug;28(8):603-5. [Medline: 12184424] [doi: 10.1097/00004770-200208000-00010]

26. Falk KW, Sedgley CM. The influence of preparation size on the mechanical efficacy of root canal irrigation in vitro. J Endod. 2005 Oct;31(10):742-5. [Medline: 16186754] [doi: 10.1097/01.don.0000158007.56170.0c]

27. Baker NA, Eleazer PD, Overbach RE, Seltzer S. Scanning electron microscopic study of the efficacy of various irrigation solutions. J Endod 1975 Apl;1(4):127-35. [doi: 10.1016/S0099-2399(75)80097-5]

28. Abou-Rass M, Piccinino MV. The effectiveness of four clinical irrigation methods on the removal of root canal debris. Oral Surg Oral Med Oral Pathol. 1982 Sep;54(3):323-8. [Medline: 6957828] [doi: 10.1016/0030-4220(82)90103-7]

29. Chow TW. Mechanical effectiveness of root canal irrigation. J Endod. 1983 Nov;9(11):475-9. [Medline: 6586975] [doi: 10.1016/S0099-2399(83)80162-9]

30. van der Sluis LW, Wu MK, Wesselink PR. The efficacy of ultrasonic irrigation to remove artificially placed dentine debris from human root canals prepared using instruments of varying taper. Int Endod J. 2005 Oct;38(10):764-8. [Medline: 16164691] [doi: 10.1111/j.1365-2591.2005.00921.x]

31. Graunaite I, Lodiene G, Maciulskiene V. Pathogenesis of Apical Periodontitis: a Literature Review. J Oral Maxillofac Res. 2012 Jan 1;2(4):e1. Review. URL: http://www.ejomr.org/JOMR/archives/2011/4/e1/v2n4e1ht.htm [Medline: 24421998] [PMC free article: 3886078] [doi: 10.5037/jomr.2011.2401]

32. Baziar H, Daneshvar F, Mohammadi A, Jafarzadeh H. Endodontic management of a mandibular first molar with four canals in a distal root by using cone-beam computed tomography: a case report. J Oral Maxillofac Res. 2014 Apr 1;5(1):e5. URL: http://www.ejomr.org/JOMR/archives/2014/1/e5/v5n1e5ht.htm [Medline: 24817995] [PMC free article: 4007371] [doi: 10.5037/jomr.2014.5105]

\section{To cite this article:}

Plotino G, Grande NM, Tocci L, Testarelli L, Gambarini G. Influence of Different Apical Preparations on Root Canal Cleanliness in Human Molars: a SEM Study.

J Oral Maxillofac Res 2014;5(2):e4

URL: http://www.ejomr.org/JOMR/archives/2014/2/e4/v5n2e4ht.pdf

doi: $10.5037 /$ jomr.2014.5204

Copyright (C) Plotino G, Grande NM, Tocci L, Testarelli L, Gambarini G. Published in the JOURNAL OF ORAL \& MAXILLOFACIAL RESEARCH (http://www.ejomr.org), 1 July 2014.

This is an open-access article, first published in the JOURNAL OF ORAL \& MAXILLOFACIAL RESEARCH, distributed under the terms of the Creative Commons Attribution-Noncommercial-No Derivative Works 3.0 Unported License, which permits unrestricted non-commercial use, distribution, and reproduction in any medium, provided the original work and is properly cited. The copyright, license information and link to the original publication on (http://www.ejomr.org) must be included. 